\title{
Lectotypification of the name Allium prattii (Amaryllidaceae)
}

\author{
Lahiri S. ${ }^{1 *} \&$ S.S. Dash ${ }^{2}$ \\ ${ }^{1}$ Central National Herbarium, Botanical Survey of India, Howrah - 711 103, India \\ ${ }^{2}$ Botanical Survey of India, CGO Complex, Salt Lake, Kolkata - 700 064, India \\ *E-mail: subhajitbsi@yahoo.com
}

\begin{abstract}
The name Allium prattii C.H.Wright (Amaryllidaceae) is lectotypified here.
\end{abstract}

Keywords: Allium, Himalaya, isolectotype, lectotype, syntype.

\section{Introduction}

The genus Allium L. (Amaryllidaceae), comprising about 987 species, is one of the largest genera in monocotyledonous angiosperms distributed in the northern hemisphere (POWO, 2020). In India, over 36 species of Allium are reported (Karthikeyan et al., 1989), of which 32 occur in the Himalaya (Sinha et al., 2019). During the floristic study of the Sikkim Himalaya, Allium prattii C.H.Wright was collected from Dzongri area of West Sikkim. A detailed survey of the literature (Wright, 1903; Stearn, 1994; Dasgupta, 2006) revealed that a proper type was not designated for the name. After studying the type specimens at BM, CAL, G, K, MPU and P (Thiers, continuously updated) and comparison with the protologue, the lectotype is selected in accordance with the provisions in Art. 9.3 of the ICN (Turland et al., 2018).

\section{Typification}

Allium prattii C.H.Wright, J. Linn. Soc., Bot. 36 (250): 124. 1903.

Lectotype (designated here): CHINA, West Szechuen (Sichuan) and Tibetan Frontier, chiefly

Received: 12.08.2020; Revised \& Accepted: 08.01.2021

Published Online: 31.03.2021 near Tachienlu at 9,000-13,500 ft., Pratt 576 (K [K000464580 digital image!]); isolecto (BM [BM000958327 digital image!]; CAL [CAL0000001088!]).

Fig. 1

Residual syntypes: CHINA, Thibet (Tibet) Oriental, Tongolo (principality of Kiala), 1893,

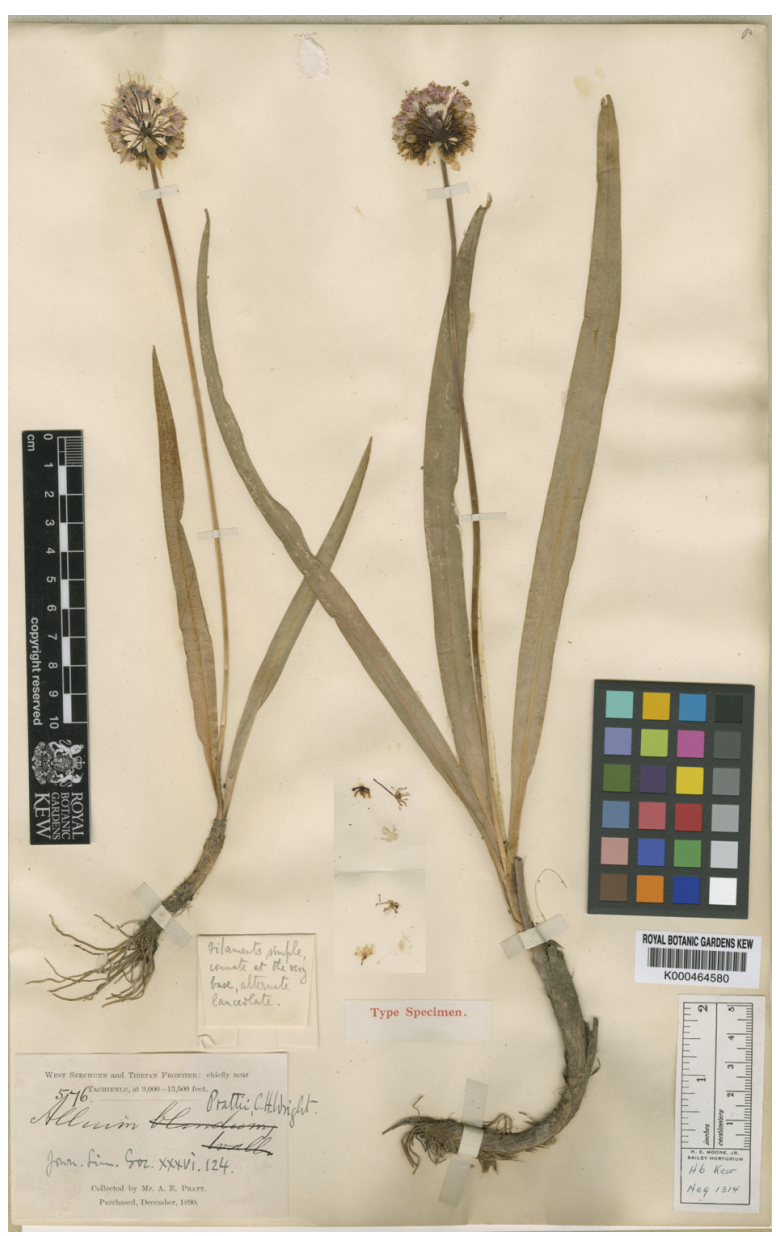

Fig. 1. Lectotype of Allium prattii C.H.Wright (A.E. Pratt 576, K000464580 http://specimens.kew.org/herbarium/K000464580.) (C) The Board of Trustees of Royal Botanical Gardens, Kew. Reproduced with permission. 
J.A. Soulié 699 (G [G00165015, G00165015 digital images!]; MPU [MPU017665 digital image!]; P [P00748041, P00748042 digital images!]).

Notes: The name Allium prattii was established by Wright in 1903 based on the specimens of A.E. Pratt collected from Szechuen (Sichuan) Tachienlu (collection no. 576) and J.A. Soulié from Tongolo (collection no. 669) at K. However, we have been unable to locate any specimens of J.A. Soulié from Tongolo (collection no. 669) - deposited at K. A search at various herbaria revealed three specimens collected by A.E. Pratt from Tachienlu (CAL0000001088!, [BM000958327; K000464580 digital images!]) and five specimens of Soulie's from Tongolo (G00165015, G00165016, MPU017665, P00748041, P00748042 digital images!). Among them, the sheet $\mathrm{K} 000464580$ has the original annotation of C.H. Wright ("filament simple connate at the very base, alternate, lanceolate") on the sheet. This specimen is complete and agrees well with the details provided in the protologue. Hence, it is designated here as the lectotype for the name, Allium prattii as per Art. 9.3 of the ICN (Turland et al., 2018).

\section{Acknowledgments}

Authors are thankful to Dr. A.A. Mao, Director, Botanical Survey of India for providing necessary facilities. We express our sincere gratitude to the Director/Curators of BM, CAL, G, K, MPU, P, and JSTOR Global Plant Sciences for putting the image of the type specimens online and for invaluable help in locating type specimens. Authors are also thankful to the Ministry of Environment, Forest \& Climate Change, New Delhi for financial Assistance under NMHS Project and Pr. Secretary -cum- Principal Chief Conservator of Forests, Department of Forests, Govt. of Sikkim for providing survey permission. Authors are thankful to anonymous reviewer for improve the manuscript.

\section{Literature Cited}

DASGUPTA S. 2006. Allium prattii Wright. In: SINGH N.P. \& M. SANJAPPA (eds.), Fascicles of Flora of India. Botanical Survey of India, Kolkata. pp. 40-42.

KARTHIKEYAN S., JAIN S.K., NAYAR M.P. \& M. SANJAPPA 1989. Florae Indicae Enumeratio: Monocotyledonae. Flora of India. Botanical Survey of India, Kolkata.

POWO 2020. Plants of the World Online. Facilitated by the Royal Botanic Gardens, Kew. Available at: http:// plantsoftheworldonline.org/ (Accessed on 07.01.2021).

SINHA B.K., DASH S.S. \& P. SINGH 2019. Plants of Indian Himalayan region: An annotated Checklist. Botanical Survey of India, Kolkata.

STEARN W.T. 1994. Allium L. In: NOLTIE H.J. (ed.), Flora of Bhutan. Royal Botanic Garden Edinburgh. pp. 76-81.

THIERS B. (continuously updated). Index Herbariorum: a global directory of public Herbaria and associated staff. Available at: http://sweetgum.nybg.org/ih (Accessed on 23.06.2020).

TURLAND N.J., WIERSEMA J.H., BARRIE F.R., GREUTER W., HAWKSWORTH D.L., HERENDEEN P.S., KNAPP S., KUSBER W.H., LI D.Z., MARHOLD K., MAY T.W., MCNEILL J., MONRO A.M., PRADO J., PRICE M.J. \& G.F. SMITH (eds.) 2018. International Code of Nomenclature for Algae, Fungi, and Plants (Shenzhen Code) adopted by the Nineteenth International Botanical Congress Shenzhen, China, July 2017. Regnum Vegetabile 159. Volume 38. Koeltz Botanical Books, Glashütten. https://doi.org/ 10.12705/Code.2018

WRIGHT C.H. 1903. Allium prattii Wright. In: FORBES F.B. \& W.B. HEMSLEY (eds.), An enumeration of all the plants known from China Proper, Formosa, Hainan, Corea, the Luchu Archipelago, and the Island of Hongkong, together with their distribution and synonymy. Part-XV. Journal of the Linnean Society of London, Botany. 36(250): 73-136. https://doi.org/10.1111/j.1095-8339.1903. tb00817.x. 